\title{
Effect of Dichloroisoproterenol on Vascular Responses to Catecholamines in Man *
}

\author{
François M. Abboud, John W. Eckstein, and Ben G. Zimmerman \\ (From the Hemodynamic Laboratory, Cardiovascular Research Laboratories, Department of \\ Internal Medicine, State University of Iowa, College of Medicine, Iowa City, Iowa)
}

In man, infusions of norepinephrine into the brachial or femoral artery cause vasoconstriction, infusions of isoproterenol produce vasodilatation, and infusions of epinephrine result in vasodilatation followed by vasoconstriction $(2-4)$. According to Ahlquist's classification of adrenergic receptors $(5,6)$, the vasoconstrictor effects of sympathomimetic amines are mediated through alpha receptors, and the vasodilator responses are subserved by beta receptors. Drugs such as phenoxybenzamine that - block alpha receptors antagonize the constrictor action of norepinephrine and epinephrine and potentiate the vasodilator effect of epinephrine but not that of isoproterenol $(4,7,8)$. These observations suggest that the actions of norepinephrine and isoproterenol are mediated through alpha and beta receptors, respectively, while the action of epinephrine is a summation of its effects on both receptors (7).

The discovery of dichloroisoproterenol (9), an antagonist that blocks selectively vasodilator adrenergic receptors (10), provided a tool for further study of the mechanism of action of catecholamines in man.

The present experiments were done to compare quantitatively the vasodilator actions of isoproterenol and epinephrine and to see if dichloroisoproterenol blocks these vasodilator actions but not the vasoconstrictor effect of epinephrine in man.

\section{Methods}

Experiments were done on 10 ambulatory male patients ranging in age from 19 to 58 years. The subjects

* Submitted for publication August 19, 1963; accepted October 23, 1963.

Supported by a research grant from the American Heart Association, grants HE-02644 and HTS-5367 from the U. S. Public Health Service and research career program awards HE-K3-17013 and HE-K6-4626 from the National Heart Institute.

Presented at the Annual Meeting of the Midwestern Section of the American Federation for Clinical Research, Chicago, Nov. 1, 1962 (1). were in good general health and without cardiovascular disease. They were studied while lying in the supine position. Room temperature was maintained at 82 to $84^{\circ} \mathrm{F}$. Each leg was placed in a limb-segment plethysmograph and suspended from the heel and lower thigh by slings padded with foam rubber. The proximal ends of the plethysmographs were just distal to the patellae, and the posterior aspects of the legs were at heart level. Care was taken to put the legs in a comfortable position and to avoid venous compression by the upper sling. The water temperature in the plethysmographs was maintained at $90^{\circ} \mathrm{F}$, and the water levels were adjusted so that the pressure on the legs was slightly higher than venous pressure. This reduced transmural venous pressure to a low constant value so that the veins could be distended freely when venous congestion was produced by inflating pneumatic cuffs placed just above the knees. Cuffs around the legs distal to the plethysmographs were inflated to suprasystolic pressure during measurements of blood flow to exclude the circulation in the lower leg and foot. The cuffs on both limbs were inflated simultaneously. Changes in limb volume were measured as changes in the height of a column of water in open tubes attached to the top of the plethysmographs. The changes in water level were taken as changes in pressure by Sanborn pressure transducers. Cournand needles were inserted into both femoral arteries. The needles were connected to manifolds upon which the syringes for intra-arterial injections were mounted. Arterial pressure was measured with a Statham transducer connected through one of the manifolds to the intra-arterial needle. Room and skin temperatures were monitored with a thermistor. The changes in water level within the plethysmographs and the intra-arterial blood pressure were recorded with a Sanborn direct-writing oscillograph. Blood flow was calculated from the rate of increase in leg volume with venous occlusion and expressed in milliliters per minute per $100 \mathrm{ml}$ of leg volume.

The drugs used in these experiments were $l$-epinephrine hydrochloride $(0.06$ to $0.25 \mu \mathrm{g}), d l$-isoproterenol hydrochloride ( 0.06 to $0.25 \mu \mathrm{g}$ ), acetylcholine chloride $(50$ to $1,000 \mu \mathrm{g}),{ }^{1}$ histamine phosphate $(0.5$ and $1.0, \mu \mathrm{g})$,

${ }^{1}$ Solutions were prepared from commercially available crystalline form before each experiment. The potency of similar solutions was tested several times in the perfused foreleg of the dog. 


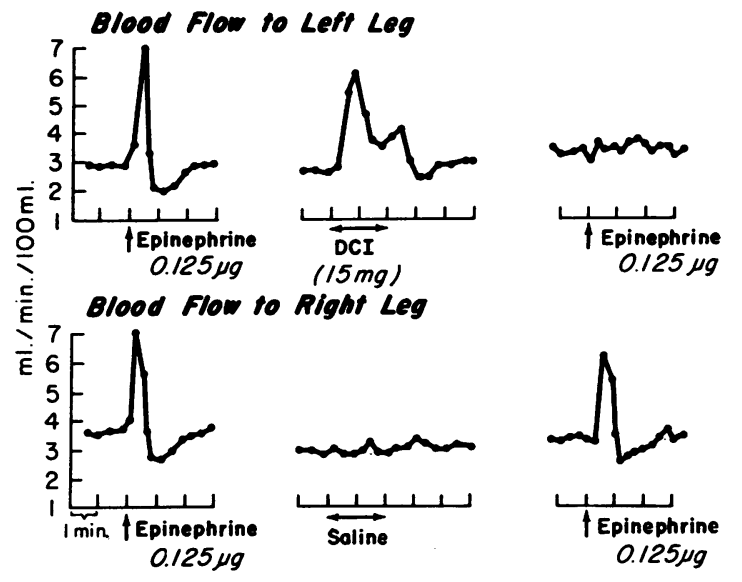

Fig. 1. EFFeCt OF INTRA-ARTERIAL INJECTIONS OF EPINEPHRINE ON BLOOD FLOW THROUGH THE CALVES BEFORE AND AFTER DICHLOROISOPROTERENOL (DCI) IN THE LEFT (EXPERIMENTAL) LEG AND BEFORE AND AFTER SALINE IN THE RIGHT (CONTROL) LEG. The antagonist (DCI) caused a transient vasodilatation. Both vasodilator and vasoconstrictor responses to epinephrine were blocked in the experimental leg after DCI and persisted in the control leg after saline.

l-norepinephrine bitartrate $(0.25 \text { and } 0.5 \mu \mathrm{g} \text { of the base })^{2}$ as agonists and dichloroisoproterenol ( 1 to $20 \mathrm{mg}$ ) as the antagonist. Dilutions of the agonists were made in $5 \%$ glucose in water, and the volume of injectate was 1 to $2 \mathrm{ml}$. Dichloroisoproterenol was diluted in 5 to 10 $\mathrm{ml}$ of normal saline and infused intra-arterially for 2 minutes. In the doses used, the drugs had no effect on systemic arterial pressure. At constant pressure the changes in flow reflected changes in vascular resistance of the calves.

The experiments were designed to obtain quantitative information on the vascular responses to catecholamines in man before and after dichloroisoproterenol. Preliminary observations indicated that the responses to the same dose of amine varied not only from one subject to another but also in the same subject throughout the experiments. For this reason each agonist was injected into both femoral arteries simultaneously; the changes in blood flow through one calf were considered as experimental values and the changes in flow through the other calf as control values. Two doses of each agonist were administered, and the pairs of injections were delivered in random order before and after the simultaneous infusion of dichloroisoproterenol in the experimental leg and of saline in the control leg. After the antagonist the changes in responses to the agonists in the experimental leg, as compared to responses observed simul-

${ }^{2}$ It is convenient to express the dose of norepinephrine in terms of the base and the doses of epinephrine and isoproterenol in terms of their salts. The doses of epinephrine and isoproterenol expressed in terms of their bases would be only slightly smaller. taneously in the control leg, could be ascribed only to a local effect of the antagonist. Variables such as the duration of the experiment, repeated injections of various drugs, and a systemic effect of dichloroisoproterenol would affect the responses in both legs equally.

Subjects rested for at least 15 minutes before the experiment was started. Blood flow was recorded during 4-minute periods before each injection. The changes in flow after the injections did not last more than 3 to 4 minutes after which a rest period of 10 minutes was allowed before the next injection. At least 3 flow curves per minute were obtained from each leg. Comparison between responses of the experimental and control legs were made by the $t$ test (11).

\section{Results}

Vasodilator effect of intra-arterial injections of isoproterenol and epinephrine. Blood flow through both calves increased sharply during the first minute after injections of isoproterenol and epinephrine (Figures 1 and 2). The two amines were

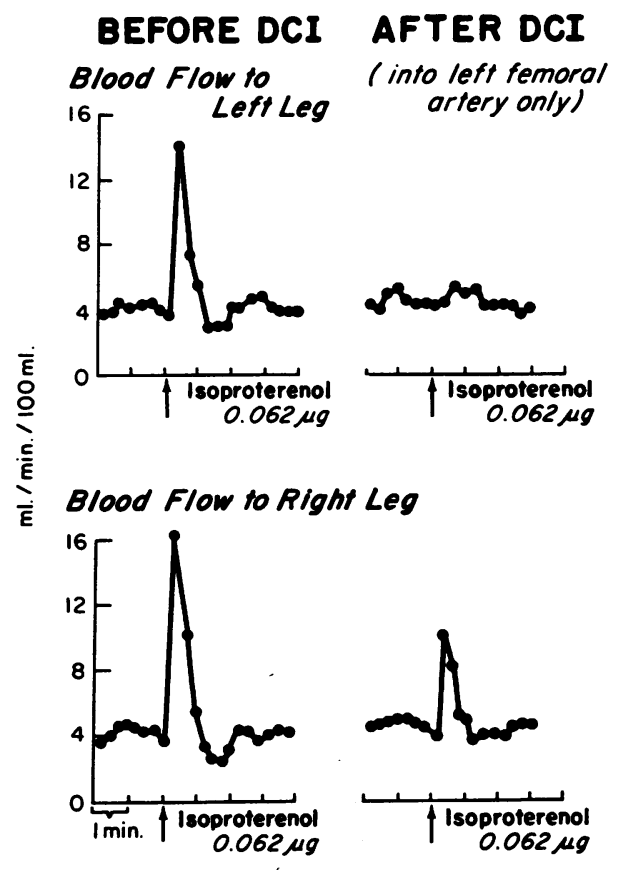

Fig. 2. EFFeCt of INTRA-ARTERIAL INJECTION OF ISOPROTERENOL ON BLOOD FLOW THROUGH THE CALVES BEFORE AND AFTER DICHLOROISOPROTERENOL (DCI, 20 MG) OR SALINE. As with epinephrine a vasoconstrictor effect is apparent after the initial large vasodilatation. Both the dilator and constrictor responses were blocked in the experimental leg. The response was reduced in the control leg also after DCI. This may have been caused in part by the large dose of antagonist $(20 \mathrm{mg})$ even though it was injected in the experimental leg only. 
TABLE I

Effect of dichloroisoproterenol $(D C I)$ on the vasodilator actions of intra-arterial

\begin{tabular}{|c|c|c|c|c|c|c|c|c|c|}
\hline \multirow[b]{4}{*}{ Exp't no. } & \multirow[b]{4}{*}{ Subject } & \multicolumn{8}{|c|}{ Changes in blood flow through the calves } \\
\hline & & \multicolumn{4}{|c|}{ Epinephrine Bet } & \multicolumn{4}{|c|}{ CI Isoproterenol } \\
\hline & & \multicolumn{2}{|c|}{ C } & \multicolumn{2}{|c|}{ Exp. } & \multicolumn{2}{|c|}{ C } & \multicolumn{2}{|c|}{ Exp. } \\
\hline & & I & II & I & II & I & II & I & II \\
\hline & & \multicolumn{8}{|c|}{$\mathrm{ml} / \mathrm{min} / 100 \mathrm{ml}$ leg volume } \\
\hline $\begin{array}{r}1 \\
2 \\
3 \\
4 \\
5 \\
6 \\
7 \\
8 \\
9 \\
10\end{array}$ & $\begin{array}{l}\text { FH } \\
\text { OP } \\
\text { LT } \\
\text { RO } \\
\text { LW } \\
\text { KE } \\
\text { AM } \\
\text { CC } \\
\text { RC } \\
\text { BM }\end{array}$ & $\begin{array}{l}+1.9 \\
+4.5 \\
+1.8 \\
+2.4 \\
+1.0 \\
+3.5 \\
+1.9 \\
+3.8 \\
+2.6 \\
+0.4\end{array}$ & $\begin{array}{l}+2.0 \\
+5.2 \\
+1.7 \\
+3.7 \\
+1.6 \\
+5.1 \\
+4.2 \\
+6.3 \\
+8.1 \\
+1.3\end{array}$ & $\begin{array}{l}+2.0 \\
+4.9 \\
+2.3 \\
+2.9 \\
+1.2 \\
+3.0 \\
+0.5 \\
+3.8 \\
+1.1 \\
+0.4\end{array}$ & $\begin{array}{l}+2.1 \\
+5.4 \\
+2.0 \\
+3.9 \\
+2.6 \\
+5.6 \\
+4.6 \\
+4.6 \\
+8.0 \\
+1.3\end{array}$ & $\begin{array}{l}+1.8 \\
+4.4 \\
+2.0 \\
+2.5 \\
+0.8 \\
+3.0 \\
+0.5 \\
+3.0 \\
+6.2 \\
+2.0\end{array}$ & $\begin{array}{l}+1.8 \\
+4.1 \\
+2.8 \\
+3.6 \\
+1.4 \\
+4.2 \\
+1.8 \\
+5.1 \\
+8.4 \\
+3.0\end{array}$ & $\begin{array}{l}+1.7 \\
+2.4 \\
+2.9 \\
+2.8 \\
+0.5 \\
+3.5 \\
+0.6 \\
+1.9 \\
+4.7 \\
+1.8\end{array}$ & $\begin{array}{l}+2.5 \\
+3.6 \\
+2.6 \\
+4.2 \\
+3.2 \\
+4.8 \\
+3.3 \\
+3.4 \\
+6.4 \\
+2.8\end{array}$ \\
\hline $\begin{array}{l}\text { Average } \\
\text { increase } \\
\text { in blood } \\
\text { flow }\end{array}$ & & +2.4 & +3.9 & +2.2 & +4.0 & +2.6 & +3.6 & +2.3 & +3.7 \\
\hline $\begin{array}{l}\text { Average } \\
\text { difference } \\
\text { between C } \\
\text { and Exp. }\end{array}$ & & & & 0.2 & -0.1 & & & 0.3 & -0.1 \\
\hline SE & & & & 0.2 & 0.2 & & & 0.3 & 0.4 \\
\hline p values $\ddagger$ & & & & $>0.4$ & $>0.5$ & & & $>0.2$ & $>0.5$ \\
\hline
\end{tabular}

${ }^{*} \mathrm{C}=$ control leg, exp. = experimental leg. $\mathrm{I}$ and II represent the doses, $0.6 \mu \mathrm{g}$ and $0.12 \mu \mathrm{g}$, respectively, except in experiments 1 and 3 where the doses were 0.12 and $0.25 \mu \mathrm{g}$. The doses of epinephrine and isoproterenol were equal in each experiment. Entries represent average changes in blood flow through both calves ( $\mathrm{C}$ and exp.) during the first minute after the simultaneous administration of the catecholamine into both femoral arteries.

$\dagger$ Indicates responses to injections given more than 20 minutes after DCI (1 mg).

$\ddagger$ The significance of the difference between responses in $\mathrm{C}$ and exp. was calculated using the paired $t$ test.

equipotent, and the higher dose of each amine caused a greater effect (Table I).

Before dichloroisoproterenol the responses in both legs were similar. Dichloroisoproterenol caused a transient increase in flow (Figure 2) and reduced significantly the vasodilator actions of isoproterenol and epinephrine in the experimental leg as compared to the control leg (Table I). The reduction in the response to isoproterenol was not significantly greater than the decrease in the response to epinephrine $(p>0.1)$.

One $\mathrm{mg}$ of dichloroisoproterenol was administered in experiments 1 and 2 . This small dose was as effective in antagonizing the action of isoproterenol and epinephrine as was a dose of $10 \mathrm{mg}$ in experiments 3 and 4, and $15 \mathrm{mg}$ in experiments 5,6 , and 7 . The duration of blockade, however, was less than 20 minutes after the smallest dose (Table I) and more than 1 hour after the larger doses. The highest dose, $20 \mathrm{mg}$, which was ad- ministered in experiments 8,9 , and 10 , reduced the responses not only in the experimental leg but also in the control leg (Table I and Figure 2).

Acetylcholine was injected into both femoral arteries in doses ranging from 50 to $100 \mu \mathrm{g}$ without causing significant increases in calf blood flow (Table II). Doses of 0.5 and $1 \mu \mathrm{g}$ of histamine caused large increases in blood flow that were unaffected by dichloroisoproterenol (Table II and Figure 3).

Vasoconstrictor effect of intra-arterial injections of isoproterenol, epinephrine, and norepinephrine. After the initial vasodilatation there were reductions in blood flow not only after epinephrine but also after isoproterenol and histamine (Table III and Figures 1, 2, and 3). Dichloroisoproterenol blocked the constrictor action of epinephrine, isoproterenol, and histamine. Norepinephrine in doses approximately 4 times greater than those of epinephrine caused similar reductions in blood 
injections of two doses of epinephrine and two doses of isoproterenol*

\begin{tabular}{|c|c|c|c|c|c|c|c|c|}
\hline \multirow[b]{4}{*}{ DCI } & \multicolumn{6}{|c|}{$\begin{array}{l}\text { Changes in blood flow through the calves } \\
\text { After DCI }\end{array}$} & & \\
\hline & \multicolumn{4}{|c|}{ Epinephrine } & \multicolumn{4}{|c|}{ Isoproterenol } \\
\hline & \multicolumn{2}{|c|}{$\mathrm{C}$} & \multicolumn{2}{|c|}{ Exp. } & \multicolumn{2}{|c|}{ C } & \multicolumn{2}{|c|}{ Exp. } \\
\hline & I & II & I & II & I & II & I & II \\
\hline \multirow{6}{*}{$\begin{array}{c}m g \\
1 \\
1 \\
10 \\
10 \\
15 \\
15 \\
15 \\
20 \\
20 \\
20\end{array}$} & & & & $m l / m i$ & eg volum & & & \\
\hline & $\begin{array}{l}+2.3 \\
+4.4 \\
+4.0 \\
+3.3 \\
+0.5 \\
+4.0 \\
+2.6 \\
+1.4 \\
+0.6 \\
+0.5\end{array}$ & $\begin{array}{l}+1.9 \\
+4.9 \\
+1.6 \\
+2.3 \\
+1.7 \\
+4.1 \\
+4.3 \\
+4.2 \\
+1.0 \\
+0.2\end{array}$ & $\begin{array}{l}+2.8 \dagger \\
+0.8 \\
+0.4 \\
+0.6 \\
+0.6 \\
+2.8 \\
+0.6 \\
+0.1 \\
+0.7 \\
+0.5\end{array}$ & $\begin{array}{l}+1.2 \\
+3.8 \dagger \\
+0.5 \\
+0.9 \\
+0.1 \\
+3.8 \\
+1.1 \\
+0.4 \\
+0.9 \\
+0.3\end{array}$ & $\begin{array}{l}+1.9 \\
+5.8 \\
+1.3 \\
+2.3 \\
+2.5 \\
+4.5 \\
+0.4 \\
+1.4 \\
+2.8 \\
+1.0\end{array}$ & $\begin{array}{l}+1.9 \\
+5.5 \\
+2.7 \\
+3.9 \\
+1.8 \\
+4.3 \\
+2.8 \\
+4.3 \\
+3.7 \\
+0.4\end{array}$ & $\begin{array}{l}+1.2 \\
-0.1 \\
+0.9 \\
+0.1 \\
+0.7 \\
+0.4 \\
+0.3 \\
-0.1 \\
+0.3 \\
+0.3\end{array}$ & $\begin{array}{l}+1.5 \dagger \\
+2.8 \dagger \\
+2.4 \\
+2.0 \\
+0.7 \\
+3.9 \\
+0.5 \\
+0.3 \\
+0.3 \\
+0.5\end{array}$ \\
\hline & +2.4 & +2.6 & +1.0 & +1.3 & +2.4 & +3.1 & +0.4 & +1.5 \\
\hline & & & 1.4 & 1.3 & & & 2.0 & 1.6 \\
\hline & & & 0.5 & 0.4 & & & 0.6 & 0.4 \\
\hline & & & $<0.05$ & $<0.01$ & & & $<0.01$ & $<0.01$ \\
\hline
\end{tabular}

TABLE II

Effect of dichloroisoproterenol $(D C I)$ on the initial response to intra-arterial injections of acetylcholine and histamine*

\begin{tabular}{|c|c|c|c|c|c|c|c|c|c|c|}
\hline \multirow{3}{*}{$\begin{array}{l}\text { Exp't } \\
\text { no. }\end{array}$} & \multirow[b]{3}{*}{ Subject } & \multirow{3}{*}{$\begin{array}{l}\text { Drugs and } \\
\text { doses }\end{array}$} & \multicolumn{4}{|c|}{$\begin{array}{l}\text { Changes in blood } \\
\text { Before DCI }\end{array}$} & \multicolumn{4}{|c|}{$\begin{array}{c}\text { flow through the calves } \\
\text { After DCI }\end{array}$} \\
\hline & & & \multicolumn{2}{|c|}{ C } & \multicolumn{2}{|c|}{ Exp. } & \multicolumn{2}{|c|}{$\mathrm{C}$} & \multicolumn{2}{|c|}{ Exp. } \\
\hline & & & I & II & I & II & I & II & I & II \\
\hline & & $\mu g$ & \multicolumn{4}{|c|}{$\mathrm{ml} / \mathrm{min} / 100 \mathrm{ml}$ leg volume } & \multicolumn{4}{|c|}{$\mathrm{ml} / \mathrm{min} / 100 \mathrm{ml}$ leg volume } \\
\hline 4 & RO & $\underset{50-1}{\mathrm{AC} \dagger}$ & +0.6 & +0.4 & +0.3 & +0.3 & +0.3 & +0.6 & +0.6 & +0.7 \\
\hline 5 & LW & $\begin{array}{l}50-100 \\
\mathrm{AC} \\
50-100\end{array}$ & +0.3 & +0.4 & -0.1 & +0.5 & +0.5 & +0.4 & +0.4 & -0.7 \\
\hline 6 & $\mathrm{KE}$ & $\begin{array}{c}\mathrm{SO} \\
\mathrm{AC} \\
100-200\end{array}$ & +0.3 & 0.0 & +0.2 & -0.1 & 0.0 & +0.4 & +0.1 & -0.1 \\
\hline $7 \ddagger$ & $\mathrm{AM}$ & $\begin{array}{l}A C \\
500-1000\end{array}$ & 0.0 & +0.1 & -0.3 & -0.3 & -0.1 & -0.6 & -0.1 & -0.8 \\
\hline 8 & $\mathrm{CC}$ & Hist. & +3.6 & +3.9 & +2.5 & +3.8 & +4.0 & +4.4 & +2.9 & +3.9 \\
\hline 9 & $\mathrm{RC}$ & Hist. & +6.2 & +6.9 & +6.2 & +6.0 & +5.7 & +7.1 & +6.3 & +8.2 \\
\hline 10 & $\mathrm{BM}$ & $\begin{array}{l}\text { Hist. } \\
0.5-1\end{array}$ & +1.5 & +2.2 & +2.2 & +2.6 & +1.2 & +1.7 & +1.7 & +2.0 \\
\hline
\end{tabular}

* See abbreviations in Table I. AC $=$ acetylcholine; hist. $=$ histamine. Entries are average changes in flow during the first minute after the injections. The doses are given; dose II was twice dose I.

$\dagger$ Acetylcholine caused little or no increase in blood flow.

In this experiment the large doses of intra-arterial acetylcholine caused a fall in mean systemic arterial pressure of 13 to $18 \mathrm{~mm} \mathrm{Hg}$ and an increase in heart rate of 7 to 10 beats per minute without any increase in blood flow through the calves but rather a decrease. All other intra-arterial injections were insufficient to cause any change in systemic pressure. Acetylcholine $(50$ and $100 \mu \mathrm{g})$ was injected into the femoral arteries in two additional experiments that were not part of this study, and it caused little or no change in blood flow. 


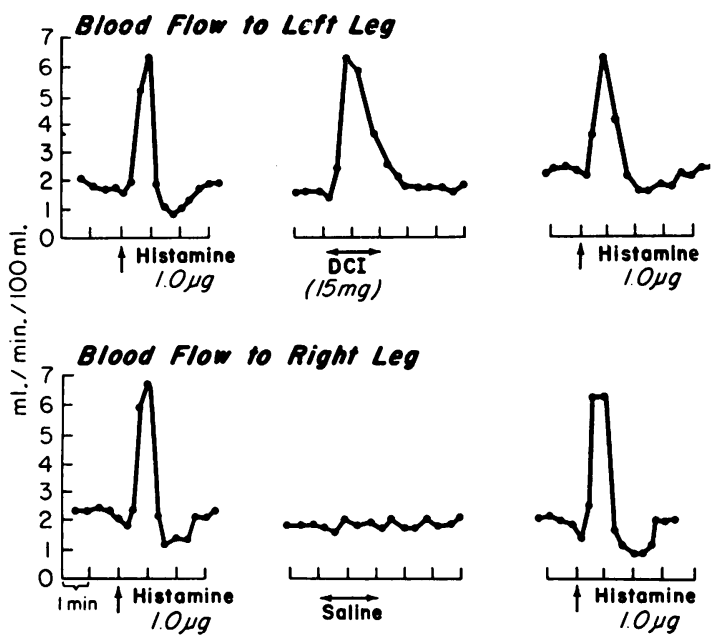

Fig. 3. EFFeCt OF INTRA-ARTERIAL INJECTIONS OF HISTAMINE ON BLOOD FLOW THROUGH THE CALVES BEFORE AND AFTER DICHLOROISOPROTERENOL (DCI) OR SALINE. As with epinephrine and isoproterenol a vasoconstrictor effect is apparent after the initial vasodilatation. The dilator effect was not blocked, but the constrictor effect was reduced after DCI.

flow that were not altered significantly by the antagonist (Table III and Figure 4).

\section{Discussion}

Two main conclusions may be drawn from these observations: 1) epinephrine and isoproterenol are equipotent in their initial vasodilator action in

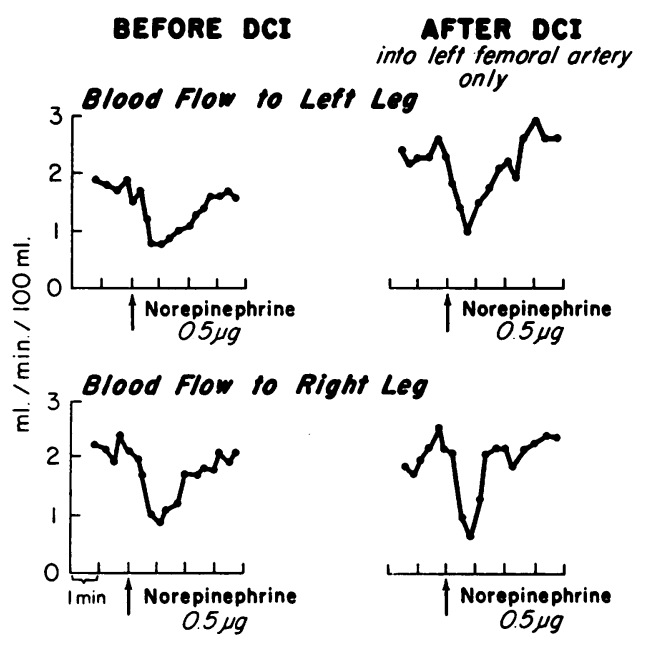

Fig. 4. EFFECT OF INTRA-ARTERIAL NOREPINEPHRINE ON BLOOD FLOW THROUGH THE CALVES BEFORE AND AFTER DICHLOROISOPROTERENOL (DCI) OR SALINE. The antagonist, in doses sufficient to block the vasoconstrictor ef fect of epinephrine, did not affect the constrictor action of norepinephrine.

man and 2) dichloroisoproterenol blocks the vasodilator effects of both amines equally. The similarity between the structure and molecular weight of these two amines, their equal potency as vasodilators, and the equal blockade of their action by dichloroisoproterenol are all compatible with the hypothesis that they both act on the same receptor proposed by Ahlquist $(5,6)$. Recently Glover,

TABLE III

Reductions in blood flow through the calves after intra-arterial injections of isoproterenol, epinephrine, histamine, and norepinephrine before and after dichloroisoproterenol*

\begin{tabular}{|c|c|c|c|c|c|c|c|c|c|}
\hline \multicolumn{5}{|c|}{ Before DCI } & \multicolumn{5}{|c|}{ After DCI } \\
\hline \multirow{2}{*}{$\begin{array}{l}\text { Resting } \\
\text { flow }\end{array}$} & \multicolumn{4}{|c|}{$\%$ decrease in flow after } & \multirow{2}{*}{$\begin{array}{l}\text { Resting } \\
\text { llow }\end{array}$} & \multicolumn{4}{|c|}{$\%$ decrease in flow after } \\
\hline & Iso. & Epi. & Hist. & Norepi. $\dagger$ & & Iso. & Epi. & Hist. & Norepi. $\dagger$ \\
\hline $\begin{array}{c}m l / m i n / 100 m l \\
\mathrm{C}\end{array}$ & $\mathrm{n}: 20$ & 20 & 6 & 6 & $\mathrm{ml} / \mathrm{min} / 100 \mathrm{ml}$ & $\mathrm{n}: 20$ & 20 & 6 & 6 \\
\hline $\begin{array}{c}2.3 \\
(0.2)\end{array}$ & $\begin{array}{l}19 \\
(3.1)\end{array}$ & $\begin{array}{c}24 \\
(3.9)\end{array}$ & $\begin{array}{c}28 \\
(4.5)\end{array}$ & $\begin{array}{c}34 \\
(8.3)\end{array}$ & $\begin{array}{c}2.3 \\
(0.3)\end{array}$ & $\begin{array}{c}18 \\
(3.7)\end{array}$ & $\begin{array}{c}22 \\
(3.8)\end{array}$ & $\begin{array}{c}22 \\
(.57)\end{array}$ & $\begin{array}{c}25 \\
(6.4)\end{array}$ \\
\hline Exp. & & & & & & & & & \\
\hline $\begin{array}{c}2.3 \\
(0.2)\end{array}$ & $\begin{array}{c}22 \\
(3.0)\end{array}$ & $\begin{array}{c}23 \\
(3.5)\end{array}$ & $\begin{array}{c}29 \\
(5.8)\end{array}$ & $\begin{array}{c}30 \\
(5.6)\end{array}$ & $\begin{array}{c}2.5 \\
(0.3)\end{array}$ & $\begin{array}{r}8 \ddagger \\
(2.4)\end{array}$ & $\begin{array}{c}14 \ddagger \\
(2.7)\end{array}$ & $\begin{array}{r}10 \ddagger \\
(4.7)\end{array}$ & $\begin{array}{l}18 \\
(3.4)\end{array}$ \\
\hline
\end{tabular}

*Iso. $=$ isoproterenol, epi. $=$ epinephrine, hist. $=$ histamine, norepi. $=$ norepinephrine, $\mathrm{C}=$ control leg, exp. $=$ experimental leg. Entries are average values, and the standard errors of the means are in parentheses. The percentage of decrease in flow was calculated from flow measurements obtained before and during the second minute after the injections.

$\dagger$ Norepinephrine $(0.25$ and $0.5 \mu \mathrm{g})$ was injected into each femoral artery before and after DCI in experiments 8,9 , and 10. The doses of the other agonists are in Tables I and II.

$\ddagger$ Indicates that the ratio response in exp.: response in $\mathrm{C}$ was significantly lower after DCI than before DCI $(p<0.05)$. 
Greenfield, and Shanks (12) presented data which indicate that vasodilator or beta adrenergic receptors may exist in the forearm of man. Our findings support their work and suggest in addition that epinephrine and isoproterenol are equipotent in their effect on the beta receptors in the blood vessels of the calf of man. This is in contrast to the results of in vitro experiments on animal tissues which indicate that isoproterenol is a more potent stimulant of beta receptors than epinephrine (13).

Acetylcholine and histamine were used as vasodilator agonists to test the specificity of the blockade. Acetylcholine produced little or no vasodilatation in the blood vessels of the calf even when doses as high as $1 \mathrm{mg}$ were injected into the femoral artery (Table II). The reason for this lack of response is not apparent. It may be that large amounts of the injectate were distributed into the thigh or that the drug was broken down rapidly by cholinesterase in the blood. In one experiment, however, the dose of intraarterial acetylcholine was sufficient to cause a fall in systemic arterial pressure and an increase in heart rate without increasing blood flow through the calves (Table II). Others ( 7 ) have observed large increases in b'ood flow through the forearm after injections of $10 \mu \mathrm{g}$ of acetylcholine into the brachial artery.

Histamine had a vasodilator effect which was equal to that of epinephrine and isoproterenol but which was not antagonized by dichloroisoproterenol, suggesting that the blockade of the vasodilator adrenergic receptors is specific.

The intra-arterial injections of epinephrine caused a biphasic response in blood flow through the calf similar to that observed with intrabrachial infusions by Allen, Barcroft, and Edholm (2) and by Duff and Swan (3). After the large initial vasodilatation that lasted 1 minute, there was a decrease in flow below control levels that also lasted 1 minute. De la Lande and Whelan suggested that the dilator effect of epinephrine is obscured partially by its more potent constrictor action (7). Blockade of the vasoconstrictor action with chlorpromazine and phenoxybenzamine augmented and prolonged the vasodilator action $(7,8)$. The response to intra-arterial epinephrine was ascribed, therefore, to a balance between a vasodilator and a vasoconstrictor effect (7).
Accordingly, blockade of the vasodilator effect of epinephrine should have augmented its vasoconstrictor action. In the present experiments, however, the vasoconstrictor response was not augmented after dichloroisoproterenol; it was reduced. Glover and associates reported a similar finding (12), but they did not attempt to show that a dose of dichloroisoproterenol which blocks the vasoconstrictor action of epinephrine reduces the constrictor action of norepinephrine. Such an experiment would determine whether the dichloroisoproterenol blocks both dilator and constrictor adrenergic receptors in man. The results reported here indicate that the vasoconstrictor response to norepinephrine was not attenuated significantly by the antagonist. The reason for the decrease in the vasoconstrictor effect of epinephrine remains obscure, but the findings indicate that the constrictor action of epinephrine as observed in these experiments is not mediated by the same constrictor mechanism that mediates the action of norepinephrine. Certain observations suggest that the constrictor effect of epinephrine may represent in part a nonspecific response to the initial large increase in flow. Stainsby and Renkin (14) showed that autoregulation of blood flow by vasoconstriction occurs after an increase in flow in skeletal muscle. Folkow (15) thinks that this phenomenon is at least in part a direct myogenic effect of stretch. If the vasoconstrictor effect of the small doses of epinephrine used in this study were related to such a phenomenon its blockade by dichloroisoproterenol would be explained readily. One could postulate that after vasodilatation there is a compensatory release of some neurohumoral agent locally that triggers the vasoconstriction. It is possible that dichloroisoproterenol blocks this release. The large initial increase in flow obtained with injections of isoproterenol and histamine was followed by vasoconstriction similar in magnitude and duration to that observed after epinephrine, suggesting that the constrictor effect may not be a specific effect of epinephrine. Neither isoproterenol nor histamine is regarded as a vasoconstrictor. As with epinephrine, blockade of the dilator action of isoproterenol was accompanied by an antagonism of its constrictor effect. Finally, the vasoconstrictor responses to epinephrine were only slightly 
smaller than those obtained with doses of norepinephrine that were approximately 4 times greater.

\section{Summary}

Simultaneous injections of epinephrine (two doses, 0.06 to $0.25 \mu \mathrm{g}$ ) and of isoproterenol (two doses, 0.06 to $0.25 \mu \mathrm{g}$ ) were made into femoral arteries of 10 subjects. The four pairs of injections were given in random order before and after simultaneous infusions of dichloroisoproterenol into the left (experimental side) and saline into the right (control side) femoral artery. Blood flow through both calves was measured with plethysmographs. Epinephrine and isoproterenol were equipotent in their initial vasodilator effect; dichloroisoproterenol reduced their vasodilator actions equally. Acetylcholine caused little or no vasodilatation in the calf. The vasodilator action of histamine was unaffected by the antagonist, dichloroisoproterenol. Vasoconstriction followed the vasodilator responses to epinephrine, isoproterenol, and histamine. The constrictor action of epinephrine, isoproterenol, and histamine was reduced by dichloroisoproterenol, but that of norepinephrine was not. The results suggest that dichloroisoproterenol selectively blocks adrenergic vasodilator receptors in blood vessels of the calf of man. Isoproterenol and epinephrine appear equipotent in their action on these receptors. The responses to the doses of epinephrine used in these experiments do not permit us to conclude that the action of epinephrine in the calf is a summation of its vasodilator and vasoconstrictor effects, since blockade of vasodilatation did not enhance the vasoconstriction.

\section{References}

1. Abboud, F. M., J. W. Eckstein, and B. G. Zimmerman. Effect of dichloroisoproterenol (DCI) on vascular responses to isoproterenol and epinephrine in man. Clin. Res. 1962, 10, 287.
2. Allen, W. J., H. Barcroft, and O. G. Edholm. On the action of adrenaline on the blood vessels of human skeletal muscle. J. Physiol. (Lond.) 1946, $105,255$.

3. Duff, R. S., and II. J. C. Swan. Further ohservations on the effect of adrenaline on the blood flow through human skeletal muscle. J. Physiol. (Lond.) 1951, 114, 41.

4. Cobbold, A. F., J. Ginsburg, and A. Paton. Circulatory, respiratory and metabolic responses to isopropylnoradrenaline in man. J. Physiol. (Lond.) 1960, 151, 539.

5. Ahlquist, R. P. A study of the adrenotropic receptors. Amer. J. Physiol. 1948, 153, 586.

6. Ahlquist, R. P. Adrenergic drugs in Pharmacology in Medicine, 2nd ed., V. A. Drill, Ed. New York, McGraw-Hill, 1958, p. 378.

7. De La Lande, I. S., and R. F. Whelan. The effect of antagonists on the response of the forearm vessels to adrenaline. J. Physiol. (Lond.) 1959, 148, 548.

8. Allwood, M. J., and J. Ginsburg. The effect of phenoxybenzamine (dibenyline) on the vascular response to sympathomimetic amines in the forearm. J. Physiol. (Lond.) 1961, 158, 219.

9. Powell, C. E., and I. H. Slater. Blocking of inhibitory adrenergic receptors by a dichloro analog of isoproterenol. J. Pharmacol. exp. Ther. 1958, 122, 480.

10. Moran, N. C., and M. E. Perkins. An evaluation of adrenergic blockade of the mammalian heart. J. Pharmacol. exp. Ther. 1961, 133, 192.

11. Snedecor, G. W. Statistical Methods, 5th ed. Ames, The Iowa State College Press, 1956, pp. 57 and 94.

12. Glover, W. E., A. D. M. Greenfield, and R. G. Shanks. Effect of dichloroisoprenaline on the peripheral vascular responses to adrenaline in man. Brit. J. Pharmacol. 1962, 19, 235.

13. Furchgott, R. F. Receptors for sympathomimetic amines in Adrenergic Mechanisms, J. R. Vane, G. E. W. Wolstenholme, and Maeve O'Connor, Eds. Boston, Little, Brown, 1960, p. 246.

14. Stainsby, W. N., and E. M. Renkin. Autoregulation of blood flow in resting skeletal muscle. Amer. J. Physiol. 1961, 201, 117.

15. Folkow, B. Innervation as a factor in control of microcirculation. Discussion. Physiol. Rev. 1960, 40, suppl. 4, 66. 